\title{
Seasonal Variation of Nutrient Pollution and Suspended Solids in the Drainage Network of Okpara Basin in Parakou (North-East of Benin)
}

\author{
Maurille P. S. Lanmandjèkpogni ${ }^{1,2}{ }^{*}$, François De Paule Codo ${ }^{1}$, Benjamin K. Yao ${ }^{2}$, Martin P. Aina1 \\ ${ }^{1}$ Laboratory of Water Science and Technology (LSTE), National Water Institute (INE), University of Abomey-Calavi (UAC), \\ Abomey-Calavi, Benin \\ ${ }^{2}$ Laboratory of Industrial Processes, Briefs, Environment and New Energy (LAPISEEN), Process Group and Environment, \\ National Polytechnic Institute Houphouet-Boigny (INP-HB), Yamoussoukro, Ivory Coast \\ Email: *paul.maurille@yahoo.fr
}

How to cite this paper: Lanmandjèkpogni, M.P.S., De Paule Codo, F., Yao, B.K. and Aina, M.P. (2018) Seasonal Variation of Nutrient Pollution and Suspended Solids in the Drainage Network of Okpara Basin in Parakou (North-East of Benin). Journal of Environmental Protection, 9, 1359-1371. https://doi.org/10.4236/jep.2018.913084

Received: October 26, 2018

Accepted: December 8, 2018

Published: December 11, 2018

Copyright $(0) 2018$ by authors and Scientific Research Publishing Inc. This work is licensed under the Creative Commons Attribution International License (CC BY 4.0).

http://creativecommons.org/licenses/by/4.0/

\section{(c) (i) Open Access}

\begin{abstract}
This work presents mainly, the seasonal variation of pollution by nutrients and suspended solids thresholds between the old urban core and the peripheral areas of the city of Parakou on the Okpara basin. The city of Parakou has been experiencing strong demographic and socio-economic growth for about two decades. A total of sixty wastewater samples from twelve sampling sites were collected in 2016 according to the AFNOR standards, between the months of March and April in the dry season, then August, September and October in the rainy season. The descriptive statistic of data (minima-maxima) indicates variations of the parameters as follows: The temperature varies between 27.05 and 30.82 , the water is a highly variable $\mathrm{pH}$ in the dry season $(5.84<\mathrm{pH}<9.14$; mean $=7.17)$ and wet $(6.28<\mathrm{pH}<9.38$; mean $=7.45)$. The reduction potential is lower in rainy season $(-89.50<\mathrm{Eh}<48.80)$ in the dry season $(-131.61<\mathrm{Eh}<42.50)$. COD and $\mathrm{BOD}_{5}$ respectively reach the highest ratio $\left(55 \mathrm{mg} / \mathrm{L} \mathrm{O}_{2}\right.$ and $\left.232.08 \mathrm{mg} / \mathrm{LO}_{2}\right)$ in the dry season than in the wet season $\left(12.00 \mathrm{mg} / \mathrm{L} \mathrm{O}_{2}\right.$ and $\left.202.40 \mathrm{mg} / \mathrm{L} \mathrm{O}_{2}\right)$. Nitrates have reached a maximum of $12.60 \mathrm{mg} / \mathrm{L}$ in the rainy season against $5.40 \mathrm{mg} / \mathrm{L}$ in the dry season. For nitrite, yielded $3.34 \mathrm{mg} / \mathrm{L}$ against $0.45 \mathrm{mg} / \mathrm{L}$ for conversely, phosphates are at $6.45 \mathrm{mg} / \mathrm{L}$ in the dry season against $2.32 \mathrm{mg} / \mathrm{L}$ in the rainy season. The mean concentrations of suspended solids are between $40 \mathrm{mg} / \mathrm{L}$ in the rainy season and $0.52 \mathrm{mg} / \mathrm{L}$ in the dry season. From the physico-chemical characterization and the chi-square independent test, this work shows mainly two results: On the one hand, apart from phosphates, concentrations of nitrates, nitrites and suspended solids on the Okpara basin in Parakou, are higher in the rainy season than in dry season. This can be explained by the variability of soil
\end{abstract}


leaching and thus shows a relative link between the quality of surface water and the hydrogeomorphic basin conditions shown by the independence test $(0.456<\mathrm{CC}<0.856)$. In addition, pollutant concentrations vary according to a decreasing gradient between the former urban core, the periphery zone and the exit of the peripheral zone.

\section{Keywords}

Pollution, Okpara, Basin, Nutrients, Eutrophication

\section{Introduction}

Surface waters are in the twenty century, the alternative explored in the new cities to supplement groundwater deficits in coverage for domestic, industrial and agricultural needs. However, several studies indicate that the surface waters that are often heavily loaded with organic and inorganic pollutants, and even heavy metal are a receptacle for anthropogenic discharges [1] [2] [3] [4] [5]. The countries in development, including Benin, for two decades show a growth rate demographic urban comparable to that observed in emerging countries worldwide [6].

From 2002 to 2013, the population of Parakou city recorded a growth of $4.81 \%$ [7]. His needs for drinking water then increased sharply. Gross annual levies on the Okpara's pumping station varied between 2 and 3 million cubic meters between 2008 and 2012 to about 23,000 subscribers in 2012 numbered [8]. These figures indicate the strategic role of Okpara dam in the drinking water supplies of people in the city of Parakou. However, the geographical position and topographic conditions of the basin, expose the Okpara reservoir to contamination by urban wastewater through rain runoff, a vector for the transport of large quantities of pollutants [9]. The reuse options observed mainly in the agricultural sector, have attracted the interest of several studies on the assessment of the quality of urban wastewater in West Africa and particularly in Benin. According to [10], the waters of the Okpara reservoir show a bacteriological pollution of 10CF/100 ml indicating an exceeding of the Beninese standards and those of the World Health Organization according to regulation of water quality for the production of water for human consumption. Similarly, in the cities of Ouagadougou and Niamey, the permanent practice of market gardening under fertilizer is a cause of the strong level of nitrates and phosphorus [11] [12]. Such high levels of nitrogen pollution are a serious threat to the pediatric health of people who consume vegetable products [13].

The urban drainage in the rainy season and hydro biological mode on sub basins Okpara, position the reservoir as a receptacle of drainage coming from the city of Parakou and some surrounding municipalities (N'Dali, Nikki, Pèrèrè and Bembèrèkè). It is necessary that the actions of preserving the water quality used 
are longer lasting effects for future generations. The algal development accelerated on the water holding Okpara, and urban drainage network of the city of Parakou, showing the expression of an increasing trophic level. This work aims mainly to contribute to the seasonal and spatial assessment of pollution of drainage water on the Okpara basin to assist in defining the catchment protection zones for drinking water in the city area.

\section{Material and Methods}

\subsection{The Study Area}

Parakou, Benin's third largest city is located in North East, about $415 \mathrm{~km}$ from Cotonou, the capital Benin's economy. Parakou is positioned between $9^{\circ} 15^{\prime}$ and $9^{\circ} 27^{\prime}$ north latitude and $2^{\circ} 31^{\prime}$ and $2^{\circ} 45^{\prime}$ east longitude and an altitude of 391.96 $\mathrm{m}$. It is bounded to the north by the municipality of N'Dali, south, east and west by the municipality of Tchaourou (Figure 1). The land cover is seen growing to the north while spreading in meaning transverse evolved a lot more slowly. The climate is Sudano Guinean type with a single rainy season between mid-May and mid-October with a peak in August. This season is followed by a dry season the rest of the year (mid-October to mid-May). Storm water and urban domestic waste are drained on the sub basin Okpara through two major collectors (collector B and collector C) towards wetlands. According to [14] about $71 \%$ of the area of the city is occupied by the Okpara basin which is organized into four sub-basins from waterways that receive wastewater season dry and rainwater during the rainy season.

\subsection{The Sampling Sites of Wastewater}

The total twelve (12) sites samples were identified. Given the runoff transit channel in the urban center and its immediate suburbs, some bridges are used as strategic benchmarks: The Okpara basin in Parakou is divided into four sub-basins which, because of the organization administrative and of socio-economic functioning of the city, are urbanizing. The sampling sites are selected outlets representing residential areas according to their occupation density level ground. Each site is designated by the initial names associated bridges.

\subsection{The Elements Sought: Nitrates, Nitrites, Phosphates and Solids Suspended}

Eutrophication of water bodies is a phenomenon whose documentation has begun since the eighteenth century. The settings officials are essentially nutrients, especially the items nitrogen and phosphorus. According to [15], a spatial and temporal variability of concentrations, east observed in surface waters on the West African coast. South pacific, atmospheric air contains between $0.1 \mu \mathrm{g} / \mathrm{m}^{3}$ and $0.4 \mu \mathrm{g} / \mathrm{m}^{3}$ of [16], with variations in the Netherlands can evolve up to 14 $\mu \mathrm{g} / \mathrm{m}^{3}$ [17]. In rainwater, the concentrations are of the order of $\mathrm{mg} / \mathrm{L}$, with a 


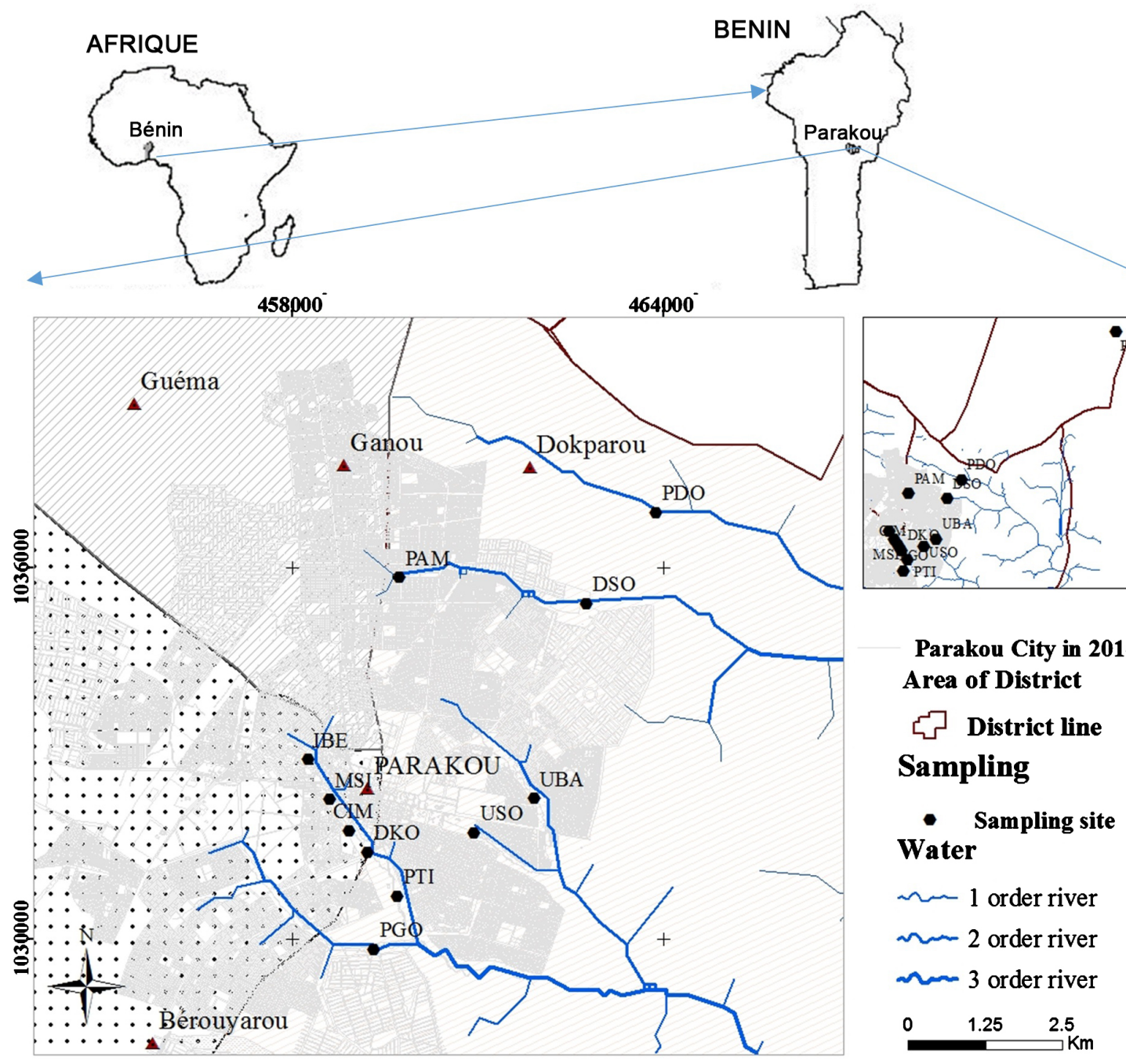

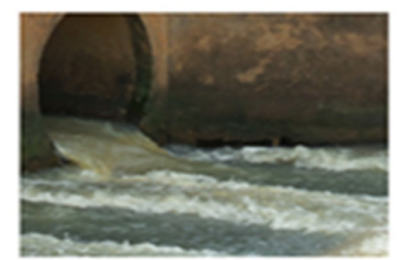

Site of Bridge of Koroborou in August 2016 (PKO)

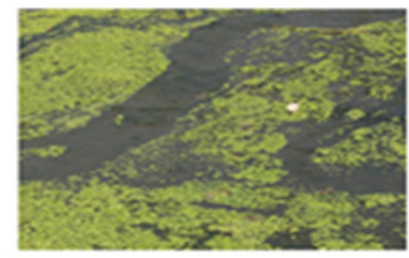

Site of Mosque Sinangourou in April 2016 (MSI)

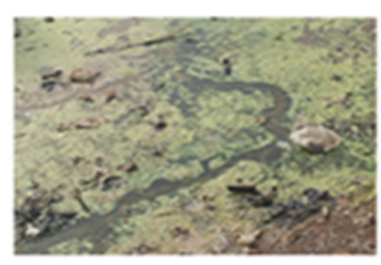

Site of Ibicus School in March 2016 (IBE)

Figure 1. Presentation map of study area and pollution level.

large influence of agricultural practices on flowing waters where rates can exceed $18 \mathrm{mg} / \mathrm{L}$ [18] indicated that despite the variety of forms it may take, phosphorus (absent in the atmospheric tank), is an essential element to algal growth in the water. The presence of phosphorus in water is an expression of the activity of hydrological responses watershed in agricultural pressure to rainfall events. Therefore, development of technology choices of activities socioeconomic and the cultural differences can be the most challenged to the maintenance cycle and transfer of nitrogen and phosphorus elements in particular surface water. 


\subsection{Sampling}

A total of 60 sewage samples were collected with a spatial distribution of twelve (12) sites. Table 1 summarizes the selection of sites and their interest in the study, the Okpara basin from upstream to downstream. At each site, the sample is carefully done at a flow control structure (bridge or culvert) and stored at $4{ }^{\circ} \mathrm{C}$ in a cooler during transport to the laboratory before being transferred to a refrigerator and stored at $-20^{\circ} \mathrm{C}$ [19]. The sample bottles of 1.5 Liter used are previously sterilized and rinsed three times with the waste water before being introduced just below the flowing water line. Indeed, given the geometric parameters of the collectors, pulling of water flows are very low (approximately $10 \mathrm{~cm}$ to $15 \mathrm{~cm}$ in the dry season, and $20 \mathrm{~cm}$ to $50 \mathrm{~cm}$ in the rainy season); These samples were taken in the surface current flows to an average depth between $10 \mathrm{~cm}$ and $20 \mathrm{~cm}$ from the free surface of the streaming water. The objective is to characterize the waters actually channelled towards the Okpara across town.

\subsection{Sampling Frequency}

The study area being characterized by a seasonal pattern unimodal, samples were collected during 2016, on a monthly time [20], end of the dry season (March and April) on the one hand, and beginning in the middle of the rainy season (August, September and October) on the other. The choice of these periods is to evaluate the effects of the deposit or leaching on sub watersheds.

\subsection{Analysis of Samples and Data Processing}

Each campaign in situ, the $\mathrm{pH}$ hydrogen potential, the temperature in degree

Table 1. Location of samples of wastewater sites.

\begin{tabular}{|c|c|c|c|c|c|c|c|c|c|}
\hline \multirow{3}{*}{ BV } & \multirow{3}{*}{ SBV } & \multicolumn{5}{|c|}{ Sampling sites identification } & \multirow{3}{*}{$\begin{array}{l}\text { Number } \\
\text { of samples }\end{array}$} & \multirow{3}{*}{ Location area } & \multirow{3}{*}{$\begin{array}{l}\text { Observation } \\
\text { Nature of site }\end{array}$} \\
\hline & & \multirow{2}{*}{ Names } & \multirow{2}{*}{ Login } & \multicolumn{3}{|c|}{ Geographic coordinates } & & & \\
\hline & & & & $\mathrm{X}$ & $\mathrm{Y}$ & $\mathrm{Z}$ & & & \\
\hline \multirow{13}{*}{ Okpara } & \multirow{3}{*}{ Kokouro } & Ibiscus School & IBE & 458,264 & $1,032,908$ & 369 & 5 & Urban & Manifold \\
\hline & & Mosque Sinangourou & MSI & 458,613 & $1,032,262$ & 360 & 5 & Urban & Manifold \\
\hline & & Muslim Cemetery & CIM & 458,935 & $1,031,760$ & 354 & 5 & Urban & Manifold \\
\hline & \multirow{2}{*}{ Dama } & Bridge Titirou & PTI & 459,713 & $1,030,703$ & 348 & 5 & Urban & Canal Earthen \\
\hline & & Bridge Gourney & PGO & 459,333 & $1,029,840$ & 345 & 5 & outskirts South-East & Canal Earthen \\
\hline & \multirow{2}{*}{ Wonka } & University (Baka) & UBA & 461,922 & $1,032,278$ & 348 & 5 & Outskirts North-East & Canal Earthen \\
\hline & & Factory SONEB & USO & 460,952 & $1,031,728$ & 362 & 5 & Outskirts North-East & Canal Earthen \\
\hline & \multirow{5}{*}{ Ganré } & Bridge Binaissi & PBI & 475,894 & $1,048,464$ & 328 & 5 & rural area & Canal Earthen \\
\hline & & Scupper Koroborou & $\mathrm{DKO}$ & 459,235 & $1,031,408$ & 355 & 5 & Rural area & Canal Earthen \\
\hline & & Bridge Douroubé & PDO & 463,887 & $1,036,905$ & 354 & 5 & Rural area & Canal Earthen \\
\hline & & Scupper Sokounon & DSO & 462,772 & $1,035,435$ & 349 & 5 & Outskirts North-East & Canal Earthen \\
\hline & & Bridge Amanwignon & PAM & 459,743 & $1,035,851$ & 367 & 5 & Outskirts North & Canal Earthen \\
\hline & & \multicolumn{2}{|c|}{ TOTAL } & & & & 60 & & \\
\hline
\end{tabular}


Celsius ${ }^{\circ} \mathrm{C}$, the EC conductivity microseconds/cm, the $\mathrm{U}$ redox potential in $\mathrm{mV}$, for each sample, are measured with the Pre devices calibrated. This is a pH-meter 3110 WTW SET 3 TW-SET, and a conductivity meter WWR EC300. The chemical oxygen demand (COD) and biological oxygen demand in five days $\left(\mathrm{BOD}_{5}\right)$ are determined according to the NFT90-103 standard and NFT90-101. Nitrates and Nitrites are determined by laboratory with the DR2400 spectrophotometer (accuracy $\pm 1 \mathrm{~nm}$ ) according to the French standard.

The statistical descriptive statistics for the maximum, minimum and mean \pm standard deviation complemented by the test of independence chi-square and the seasons to indicate the link change to the $5 \%$ threshold is analysis. The statistical analysis was performed with the statistical software SPSS.21 (Statistical Package for the Social Sciences) according to its large possibilities to perform multivariable analysis tests.

\section{Results and Discussion}

\subsection{Seasonal Variations of the Parameters to the Scale of Sampling Sites}

\subsubsection{Variation of the Concentrations of Nitrate $\left(\mathrm{NO}_{3}^{-}\right)$ and Nitrites $\left(\mathrm{NO}_{2}^{-}\right)$}

An inverse inter-seasonal variation in nitrate and nitrite concentrations according to whether the sampling sites are in the urban core or in the periphery. From the school Ibiscus (IBE) to bridge Titirou (ITP) in urban core, the nitrate concentration ranges between $5.40 \mathrm{mg} / \mathrm{L}$ and $6.93 \mathrm{mg} / \mathrm{L}$ (mean $=6.38 \pm 0.61 \mathrm{mg} / \mathrm{L}$ ) in the rainy season and $0.5 \mathrm{mg} / \mathrm{L}$ to $3.6 \mathrm{mg} / \mathrm{L}$ (mean $=1.67 \pm 1.16 \mathrm{mg} / \mathrm{L})$ in the dry season. $\mathrm{Ni}$ trites have lower concentrations ranging from $0.39 \mathrm{mg} / \mathrm{L}$ to $2.14 \mathrm{mg} / \mathrm{L}$ (mean $=1.34$ $\pm 0.62 \mathrm{mg} / \mathrm{L}$ ) in the rainy season and $0.01 \mathrm{mg} / \mathrm{L} 0.06 \mathrm{mg} / \mathrm{L}$ (mean $=0.03 \pm 0.02$ $\mathrm{mg} / \mathrm{L}$ ) seasonal dried. Low concentrations of nitrates on the sites sampled in the crown Device urban area vary between $0.24 \mathrm{mg} / \mathrm{L}$ to $1.03 \mathrm{mg} / \mathrm{L}$ (mean $=0.63 \pm 0.29$ $\mathrm{mg} / \mathrm{L}$ ) for $\mathrm{PGO}$ sites, BAK, PSO, BIN, PKO and PDO in the rainy season and 0.01 $\mathrm{mg} / \mathrm{L} 3.07 \mathrm{mg} / \mathrm{L}($ mean $=0.79 \pm 1.06 \mathrm{mg} / \mathrm{L})$ in the dry season. Sites SONEB $(\mathrm{SON})$ and the Bridge Amanwignon (PAM) located at the exit of the urban center, are considered sites representing the semi-urban area. They have a mean concentration of $3.51 \pm 0.32 \mathrm{mg} / \mathrm{L}$ and $0.30 \pm 0.11 \mathrm{mg} / \mathrm{L}$ respectively in the rainy season and dry season for nitrates. The concentrations of nitrite ranging from $0.02 \mathrm{mg} / \mathrm{L}$ to 0.25 $\mathrm{mg} / \mathrm{L}$ and an average of $0.13 \pm 0.09 \mathrm{mg} / \mathrm{L}$ and $0.02 \pm 0.01 \mathrm{mg} / \mathrm{L}$ in the dry season. In rainy season, it was noted in peripheral area between nitrite concentrations 0.01 $\mathrm{mg} / \mathrm{L}$ and $0.11 \mathrm{mg} / \mathrm{L}($ mean $=0.06 \pm 0.04 \mathrm{mg} / \mathrm{L})$ in the rainy season, and then 0.02 $\mathrm{mg} / \mathrm{L} 0.25 \mathrm{mg} / \mathrm{L}$ (mean: $0.13 \pm 0.09 \mathrm{mg} / \mathrm{L}$ ) in the dry season.

\subsubsection{Variation of the Concentrations of Suspended Solids (SS) and Phosphate ( $\mathrm{PO}_{4}^{3-}$ )}

Outside the Titirou bridge, the values obtained in the rainy season in the urban core, ranging from $6.67 \mathrm{mg} / \mathrm{L}$ and $8.33 \mathrm{mg} / \mathrm{L}$ with an average $6.11 \pm 2.08 \mathrm{mg} / \mathrm{L}$. 
Of the semi urban peripheral ring at the most distant point (BIN), SS concentrations are between $6.67 \mathrm{mg} / \mathrm{L} 40.00 \mathrm{mg} / \mathrm{L}$ with an average of $22.21 \pm 12.06 \mathrm{mg} / \mathrm{L}$. In the dry season, bridge Gourney (PGO) and Titirou (PTI) presented respectively large values of SS $(14.32 \mathrm{mg} / \mathrm{L}$ and $9.83 \mathrm{mg} / \mathrm{L})$; other sites, have a concentration between $0.87 \mathrm{mg} / \mathrm{L}$ and $2.58 \mathrm{mg} / \mathrm{L}$; or $83 \%$ of donor sites, the average is $1.48 \pm 0.43 \mathrm{mg} / \mathrm{L}$ in the dry season. In the dry season, the highest concentrations of phosphate were obtained at the mosque and Sinangourou Koroborou (SIN: $4.30 \mathrm{mg} / \mathrm{L}$ and PKO: $4.26 \mathrm{mg} / \mathrm{L}$ ), followed by bridges Gourney (PGO: $2.48 \mathrm{mg} / \mathrm{L}$ ) and Douroubé (PDO: $2.30 \mathrm{mg} / \mathrm{L}$ ); Other sites showed concentrations of phosphate between $0.23 \mathrm{mg} / \mathrm{L}$ to $1.21 \mathrm{mg} / \mathrm{L}$ (mean: $0.53 \pm 0.36 \mathrm{mg} / \mathrm{L}$ ) in the peripheral area. In urban core, the average is $2.07 \pm 1.37 \mathrm{mg} / \mathrm{L}$ with a maximum of $4.30 \mathrm{mg} / \mathrm{L}$ and a minimum of $0.55 \mathrm{mg} / \mathrm{L}$. The rainy season is periphery to values between $0.34 \mathrm{mg} / \mathrm{L}$ and $1.04 \mathrm{mg} / \mathrm{L}$ (mean: $0.61 \pm 0.20 \mathrm{mg} / \mathrm{L}$ ) $1.10 \pm 0.56 \mathrm{mg} / \mathrm{L}$ and ranging from $0.56 \mathrm{mg} / \mathrm{L}$ and $1.82 \mathrm{mg} / \mathrm{L}$ in the urban core.

\subsection{Inter-Seasonal Variation of Parameters across the Watershed Okpara in Parakou}

Table 2 shows the maximum, minimum and mean and standard deviations of the variables throughout the Okpara basin. Table 3 shows the relatively high dependence of the variation in the occurrence of nitrogen and phosphorous pollution parameters according watersheds. To nitrates and nitrites, there is an increase of the maximum concentrations, minimum and average accompanied by a wide spread in the rainy season compared to the dry season. Thus, average rates ranged from $0.80 \pm 1.17 \mathrm{mg} / \mathrm{L}$ to $3.57 \pm 3.47 \mathrm{mg} / \mathrm{L}$ for nitrate and nitrite increased from $0.08 \pm 0.13 \mathrm{mg} / \mathrm{L}$ to $0.42 \pm 0.78 \mathrm{mg} / \mathrm{L}$. The situation is reversed for the average concentrations of phosphates with a dispersion of 2.07 to 0.57

Table 2. Seasonal concentration of some physic-chemical parameters on the BV Okpara in Parakou.

\begin{tabular}{|c|c|c|c|c|c|c|c|c|c|c|}
\hline \multicolumn{11}{|c|}{ Seasons } \\
\hline \multirow[b]{2}{*}{ BV } & \multirow[b]{2}{*}{ Settings } & \multirow[b]{2}{*}{ Units } & \multicolumn{4}{|c|}{ Dry Season } & \multicolumn{4}{|c|}{ Rainy season } \\
\hline & & & $\operatorname{Max}$ & Min & Moy & Ec & $\operatorname{Max}$ & Min & Moy & Ec \\
\hline \multirow{10}{*}{ 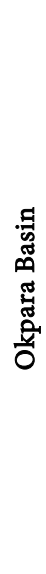 } & Nitrates & $\mathrm{mg} / \mathrm{L}$ & 5.40 & 0.00 & 0.80 & 1.17 & 12.60 & 0.10 & 3.57 & 3.47 \\
\hline & Nitrites & $\mathrm{mg} / \mathrm{L}$ & 0.45 & 0.00 & 0.08 & 0.13 & 3.34 & 0.00 & 0.42 & 0.78 \\
\hline & Phosphates & $\mathrm{mg} / \mathrm{L}$ & 6.40 & 0.25 & 2.45 & 2.07 & 2.32 & 0.20 & 0.87 & 0.57 \\
\hline & SS & $\mathrm{mg} / \mathrm{L}$ & 0.52 & 0.00 & 0.08 & 0.13 & 40.00 & 0.00 & 7.23 & 11.85 \\
\hline & EC & $\mu \mathrm{s} / \mathrm{cm}$ & 1460.43 & 48.80 & 558.18 & 413.46 & 3337.80 & 40.50 & 580.00 & 565.80 \\
\hline & $\mathrm{pH}$ & $\mathrm{UpH}$ & 9.14 & 5.84 & 7.17 & 0.79 & 9.38 & 6.28 & 7.45 & 0.78 \\
\hline & $\mathrm{T}$ & ${ }^{\circ} \mathrm{C}$ & 33.00 & 28.00 & 30.82 & 1.23 & 29.50 & 24.50 & 27.05 & 1.33 \\
\hline & $\mathrm{Eh}$ & $\mathrm{mV}$ & 42.45 & -131.61 & -36.12 & 51.80 & 48.80 & -89.50 & -10.16 & 42.07 \\
\hline & COD & $\mathrm{mg} / \mathrm{L}$ & 232.08 & $<1$ & 46.39 & 73.63 & 202.40 & $<1$ & 58.22 & 65.68 \\
\hline & $\mathrm{BOD}_{5}$ & $\mathrm{mg} / \mathrm{L}$ & 55.00 & $<1$ & 8.78 & 18.73 & 12.00 & $<1$ & 4.50 & 4.80 \\
\hline
\end{tabular}


Table 3. Independence test for changes on watershed $(\alpha=5 \%)\left(\mathrm{H}_{0}\right.$ : Inexistence de lien de dépendance; $\mathrm{H}_{1}$ : Existence de lien de dépendance).

\begin{tabular}{cccccc}
\hline Crossing & Pearson chi-square & P-value & V de Cramer & C.C & Décision \\
\hline Basin x Nitrates & 85.201 & 0.09 & 0.688 & 0.766 & $\mathrm{H}_{1}$ \\
Basin x Nitrites & 140.500 & 0.35 & 0.883 & 0.837 & $\mathrm{H}_{1}$ \\
Basin x MES & 15.738 & 0.61 & 0.296 & 0.456 & $\mathrm{H}_{1}$ \\
Basin x Phosphates & 165.20 & 0.11 & 0.958 & 0.856 & $\mathrm{H}_{1}$ \\
\hline
\end{tabular}

and the average of $2.45 \mathrm{mg} / \mathrm{L}$ to $0.87 \mathrm{mg} / \mathrm{L}$ of the dry season to the rainy season.

Suspended solids (SS) ranged averaged $0.08 \pm 0.13 \mathrm{mg} / \mathrm{L}$ seasonal dry against $7.23 \pm 11.85 \mathrm{mg} / \mathrm{L}$ in the rainy season. Waste water from the rainy season are more mineralized $(580.00 \pm 565.80 \mu \mathrm{S} / \mathrm{cm}, \max =3337.80 \mu \mathrm{S} / \mathrm{cm})$ in the dry season $(558.18 \pm 413.46 \mu \mathrm{S} / \mathrm{cm}$ with a $\max =1460.43 \mu \mathrm{S} / \mathrm{cm})$. The quality has a low tendency to alkalizing in the rainy season $(\mathrm{pH}=7.45 \pm 0.78)$ with an average temperature which varies little $\left(30.82^{\circ} \mathrm{C} \pm 1.23^{\circ} \mathrm{C}\right.$ ) in dry season to $27.05^{\circ} \mathrm{C} \pm$ $1.33^{\circ} \mathrm{C}$ in the rainy season. The redox potential indicates that the reducing power is stronger in the dry season $(-131 \mathrm{mV}<\mathrm{Eh}<42.05 \mathrm{mV})$ compared to the rainy weather and the reduction of capacity is weakened in favour of the oxidizability $(-89.50 \mathrm{mV}<\mathrm{Eh}<48.80 \mathrm{mV})$. The degradation of organic matter chemically applicant is oxygen in any season. The average values showed an increase of $\operatorname{COD}($ mean $=58.22 \mathrm{mg} / \mathrm{L})$ and a decrease in $\mathrm{BOD}_{5}($ mean $=4.50 \mathrm{mg} / \mathrm{L})$ in the rainy season against $\mathrm{COD}($ mean $=46.39 \mathrm{mg} / \mathrm{L}) \mathrm{BOD}($ mean $=8.78 \mathrm{mg} / \mathrm{L})$ in the dry season.

\subsection{Discussion}

The chi-square test shows that apart from suspended solids, phosphorus and nitrogen pollution has a very related to watershed variability $(0.76<\mathrm{CC}<0.83)$. The relatively weak relationship ( $\mathrm{CC}=0.45$ ) obtained for $\mathrm{SS}$ is due to the erosive rainfall events and soil stability especially upstream-urban basins where the coated surfaces (paved) are becoming larger. The nitrogen and phosphorous pollution is a major factor assessment trophic level of water [21]. Some work suggests a risk of haemoglobin linked to the quality of water intended for the production of human consumption of water [22].

For nitrates and nitrites, the average and maximum concentrations obtained in rainy periods are higher than in dry period regardless of the scale of analysis. The values obtained in the dry season $(\max =5.40 \mathrm{mg} / \mathrm{L}$, mean $=0.80 \mathrm{mg} / \mathrm{L})$ to nitrate and $(\max =0.45 \mathrm{mg} / \mathrm{L}$ mean $=0.08 \mathrm{mg} / \mathrm{L})$ nitrites, are below international standard requirements (Table 4 ). These results indicate moderate contamination of urban discharges on the Okpara basin in Parakou in the dry season. The variability of nutrient levels (nitrogen pollution) in the surface water in urban areas is dependent on hydro climate conditions. From the case of low Moulaya in Morocco [23] explained variation nitrate concentrations between $7.61 \mathrm{mg} / \mathrm{L}$ Oued $\mathrm{Za}$ and $25.96 \mathrm{mg} / \mathrm{L}$ Oued Tizegrhane by soil leaching difference 
Table 4. Summary of some standards and recommendations.

\begin{tabular}{ccccc}
\hline Agent chimique & $\begin{array}{c}\text { Normes } \\
\text { Québécoise }\end{array}$ & $\begin{array}{c}\text { Canadian } \\
\text { Recommandation }\end{array}$ & $\begin{array}{c}\text { Normes } \\
\text { américaines }\end{array}$ & OMS 2004 \\
\hline Nitrates & - & $10 \mathrm{mg}-\mathrm{N} / \mathrm{L}$ & $10 \mathrm{mg}-\mathrm{N} / \mathrm{L}$ & $50 \mathrm{mg}-\mathrm{NO}_{3}^{-} / \mathrm{L}$ \\
Nitrites & $1 \mathrm{mg}-\mathrm{N} / \mathrm{L}$ & $1 \mathrm{mg}-\mathrm{N} / \mathrm{L}$ & $1 \mathrm{mg}-\mathrm{N} / \mathrm{L}$ & $0.1 \mathrm{mg}-\mathrm{NO}_{2}^{-} / \mathrm{L}$ \\
Nitrates + Nitrites & $10 \mathrm{mg}-\mathrm{N} / \mathrm{L}$ & - & $10 \mathrm{mg}-\mathrm{N} / \mathrm{L}$ & - \\
Phosphates & - & - & - & $0.2 \mathrm{mg}-\mathrm{PO}_{4}^{3-} / \mathrm{L}$ \\
\hline
\end{tabular}

Source: Scientifics group on water, National Institute Québec, 2003 and WHO, 2004.

and contributions in diffuse pollution dry periods. The same was done on the raw sewage in the Oued Ouislane Morocco [24]. On Okpara in rainy period, only IBE and CIM stations have reached the maximum rates of the basin, 12.60 $\mathrm{mg} / \mathrm{L}$ and $10.40 \mathrm{mg} / \mathrm{L}($ mean $=6.38 \pm 0.61 \mathrm{mg} / \mathrm{L})$ of nitrates and $3.34 \mathrm{mg} / \mathrm{L}$ (mean $=1.67 \pm 1.16 \mathrm{mg} / \mathrm{L}$ ) of nitrite in August in the urban core. The levels almost ten times lower obtained in the peripheral ring can be explained in part by land occupation rate that decreases with distance from the city center to the regions peripheral devices [25]. According to [26] and [27] the harm caused by nitrite concentration moderate rainy periods is 10 times higher than that of nitrates. Indeed, during the dry period (Mid-November to mid-May), runoff rate in urban drainage channels Parakou is very low (water layer of approximately 10 $\mathrm{cm}$ to $15 \mathrm{~cm}$ ), and the rate of flow is favourable to deposit materials from biological degradation or chemical organic matter. The runoff into the canals of the urban core is supplied in this period mainly through direct domestic waste in the collectors and then posed a risk of a permanent threat to the quality of surface water [28] [29]. The risk of methemoglobinemia in Parakou would be very low at the time of our work, as the conclusions of [30] on consumer water from the city of ANABA (Algeria). However, for all stations in peripheral areas concentrations were fall $(\mathrm{Min}=5.4 \mathrm{mg} / \mathrm{L}$ at PTI, and $\max =1.03 \mathrm{mg} / \mathrm{L}$ at PSO $)$ for nitrates and $(1.44 \mathrm{mg} / \mathrm{L}$ from IBE to 0.04 at $\mathrm{PDO})$ for nitrites, right out of the artificial urban drainage network. This significant fall can explained by the terms geomorphology of the output of the artificial basin with a network of reinforced concrete coating resulting in a highly grassed earth channel in the rainy season with a background in granular materials. Part of the nitrogen pollution has infiltrated in favour of infiltration rates, soil on the sites of urban periphery. High concentrations of nitrates in the range of $120 \mathrm{mg} / \mathrm{L}$ were observed in the city of Abidjan with 4,693,912 inhabitants [31] according to [32] with great variability explained by the luxury of rejecting various sectors in the sewers of the city. The populous districts (Yopougon...) are transmitters of larger pollutant loads as residential areas (Riviera...), and when the climate conditions of hydro and geomorphological are favourable, nitrates contribute significantly to increase ground water vulnerability [4] Contributions in nitrogen pollution may also be due to the great cultural and cultic value that Aboriginal people in Parakou 
breeding and horse ownership in each Wassangari household in town, and the cattle of Fulani periphery [33]. The high temperatures of $30.82^{\circ} \mathrm{C} \pm 1.33^{\circ} \mathrm{C}$ in the dry season and $27.05^{\circ} \mathrm{C} \pm 1.33^{\circ} \mathrm{C}$ in the rainy season were recorded and are adjacent the results obtained on the lagoon Porto Novo and Lake Nokoué in [21] [34] and Aghien lake in Ivory Coast [3] This heat can be explained by the fact that the samples were taken in the late morning ( $10 \mathrm{~h}$ to $12 \mathrm{~h}$ ) or early afternoon $(12 \mathrm{~h}$ to $13 \mathrm{~h}$ ). The walls of the collectors being reinforced concrete cement low water slides $(10 \mathrm{~cm}$ to $15 \mathrm{~cm}$ in the dry season and about $20 \mathrm{~cm}$ to $50 \mathrm{~cm}$ in the rainy season) receive a high solar radiation especially in sunny weather. Seasonal variation of temperature is essentially only because of the time and not the sampling site. These temperature values are accompanied by a moderately alkaline medium hydrogen potential $(7.17 \pm 0.79$ in dry season and $7.45 \pm 0.78$ in the rainy season). Also, the extreme values (5.84 and $9.14 \mathrm{UpH}$ dry season) and (9.38 $\mathrm{UpH}$ to $6.28 \mathrm{UpH}$ and in the rainy season) indicate a moderate seasonal variability of the acidity or alkalinity of releases. The central core of the city to the outskirts, there is a decrease in alkalinity and a rise in acidity of releases with much mineralized water in the rainy season. The industrial waste water discharges certainly influence intrusion in some places the $\mathrm{pH}$ in the sewer system of the city, including measuring stations IBE, MSI, and CIM, PTI all located in the Metropolitan Area. More acidic water is obtained in the peripheral crown (PAM, SON, BAK, and PGO) and the most distant points (PBI, PDO, PSO $\mathrm{PKO}$ ) of the urban core. The contribution oxygen of the air atmospheric added to the effects of high temperatures accelerates the photosynthetic activity by location.

Considering the concentrations obtained for phosphates, in both seasons, the WHO class standard wastewater on the Okpara basin in Parakou among the polluted water as well as in the urban core in the peripheral areas. According intake watershed phosphorus generally is manageable for the preservation of large bodies of water, but the variability of the sources inertia is a major obstacle especially in aquatic environments exposed to eutrophication. The concentrations of phosphate increases with the flow rates; but otherwise made the observation on some samples of the Okpara basin between the dry and rainy seasons the study period, can be explained by the phosphorus retention effect in the buffer zones [18]. Several sites are used for the vegetable production in Parakou and its peripheral areas. The MIC and PTI sites are located on the base of the manifold and supply the market gardening areas on the bank. The concentrations of phosphates have not fallen unlike PGO sites, PSO, BAK where the channels are very grassy land and in the rainy season. The effects of emission and retention of phosphorus pollution alternate in the Okpara basin with a predominance of those of retention.

\section{Conclusion}

Knowledge of pollution modes by nutrients (nitrogen and phosphorus) is an as- 
pect in determining the fight against eutrophication and control of the surface water vulnerability for better access of the population to long-term drinking water. This study attempted to assess the thresholds and the differences in pollution by nutrients between the old urban core and expansion areas on the outskirts of the city of Parakou in Okpara basin. The results indicate a critical role of soil leaching by runoff, resulting in increased concentrations of these pollutants in the rainy season. Also, the occurrence of pollution parameters varies greatly basins and refocuses the debate on a possible correlation between urban development indicators and wastewater degradation levels rejected for better management of modes anthropization watershed, especially in developing countries.

\section{Acknowledgements}

The authors demonstrate their gratitude to the embassy of the Netherlands which, thanks to NICHE-BEN-167 project focused financial support to the implementation of field activities and analysis of samples.

\section{Conflicts of Interest}

The authors declare no conflicts of interest regarding the publication of this paper.

\section{References}

[1] Hallet, V. (2004) Modélisation mathématique de l'évolution, à long terme, des teneurs en nitrates dans la nappe aquifère des craies du Crétacé de Hesbaye. Journal of Water Science, 17, 3-22.

[2] Ahoussi, E.K., Soro, N., Kouassi, A.M., Soro, G. and Koffi, Y.B. (2010) Application des méthodes d'analyses statistiques multivariées à l'étude de l'origine des métaux lourds $\left(\mathrm{Cu}^{2+}, \mathrm{Mn}^{2+}, \mathrm{Zn}^{2+}\right.$ et $\left.\mathrm{Pb}^{2+}\right)$ dans les eaux des nappes phréatiques de la ville d'Abidjan. International Journal of Biological and Chemical Sciences, 4, 1753-1765.

[3] Traoré, A., Soro, G., Kouadio, E.K., Bamba, B.S., Oga, M.S., Soro, N. and Biemi, J. (2012) Evaluation des paramètres physiques, chimiques et bactériologiques des eaux d'une lagune tropicale en période d'étiage : la lagune Aghien (Côte d'Ivoire). International Journal of Biological \& Chemical Sciences 6, 7048-7058.

[4] Deh, S.K., Kouamé, K.J., Salé, M.B., Tanoh, K.J-J., Anani, A.B., Signo, K.H., Jourda, J.P. and Biémi, J. (2012) Evaluation de la vulnérabilité spécifique aux nitrates $\left(\mathrm{NO}_{3}\right)$ des eaux souterraines du District d'Abidjan (Sud de la Côte d'Ivoire). International Journal of Biological of and Chemical Sciences, 6, 1390-1408.

https://doi.org/10.4314/ijbcs.v6i3.40

[5] Yao, K.M., Metongo, B.S., Trokourey, A. and Bohra, Y. (2009) La pollution des eaux de la zone urbaine d'une lagune tropicale par les matières oxydables (lagune Ebrié, Côte d'Ivoire). International Journal of Biological \& Chemical Sciences, 3, 755-770. https://doi.org/10.4314/ijbcs.v3i4.47168

[6] FNUAP (2009) State of the World Population. Facing a Changing World: Women, Population and Climate. [L'état de la population mondiale. Faire face à un monde en mutation: femmes, population et climat.] FNUAP, New York.

[7] INSAE (2014) National Institute of Statistics Applied and the Economy, Benin.

[8] EAA (2014) Rapport sur l'état des lieux dans le cadre de l'appui à l'élaboration du 
Plan Directeur d'Assainissement de la ville de Parakou. SONEB, Rapport Final.

[9] Rossi, L. (1998) Qualité des eaux de ruissellement urbaines. Thèse de Doctorat, Ecole Polytechnique Fédérale, Lausanne.

[10] Hounsou, M.B., Agbossou, E.K., Ahamidé, B. and Akponikpè, I. (2010) Bacteriological Water Quality of the Ouémé Basin: The Case of Fecal and Total Coliforms in the Water Reservoirs of the Okpara, Djougou and Agbado. International Journal of Biological and Chemical Sciences, 4, 377-390.

[11] Adamou, R., Alhou, B. and Garba, Z. (2015) Impact de la pollution anthropique du fleuve Niger sur la prolifération de la jacinthe d'eau. Journal des Sciences, 15, 25-38.

[12] Koné, M., Bonou, L., Bouvet, Y., Joly, P. and Koulidiaty, J. (2009) Study of Water Pollution by Agricultural Inputs: Case of Five Intensive Agriculture Areas in Burkina Faso. Sud Science \& Technology, 17, 6-15.

[13] Agossou, J., Afouda, L., Adédémy, J.D., Noudamadjo, A., N’Da Tido, C., Ahohoui, E.C., Tovihoudji, P., Mazou, F., Fayomi, B., Akpona S., Adéothy-Koumakpai, S. and Ayivi, B. (2014) Risques de fièvres typhoïdes et paratyphoïdes liés à l'utilisation des eaux usées en agriculture urbaine et péri-urbaine : cas du maraîchage dans la ville de Parakou (Bénin). Environnement Risques \& Sante, 13, 405-416.

[14] Abdoulaye, A.R. and Ramanou, A.Y.M.A. (2015) Urban Market-Gardening in Parakou (Republic of Benin): Spatial Dynamics, Food Security, Protection of the Environment and Creation of Employments. Journal of Geoscience and Environment Protection, 3, 93-103. https://doi.org/10.4236/gep.2015.35011

[15] Démè, G.I. and Tourey, D.R. (1990) Spatio Temporal Variability of the Temperature, Nitrates and of the Chlorophyll off the Coast of Senegal. Documents Scientist. Center of Oceanographic Research Dakar Tiaroy. Senegalese Institute of Agricultural Research, 122, 22.

[16] Prospero, J. and Savoie, D. (1989) Effect of Continental Sources We Nitrate Concentrations over the Pacific. Springer, 339, 687-689.

[17] Jansen, V. and Roemer (1989) Nitrate and Nitrites in Drinking-Water. World Health Organization.

[18] Dorioz, J.M. (2013) Mechanisms and Control of Agricultural Diffuse Pollution: The Case of Phosphorus and Its General Application. Biotechnology, Agronomy, Society and Environment, 17, 277-291.

[19] Rodier, J., Legube, B., Merlet, N., et al. (2009) L'analyse de l'eau. 9e édition, entièrement mise à jour, Dunod, Paris.

[20] Birgand, F., Faucheux, C., Gruau, G., Augeard, B., Moastar, F., Meybeck, F., Bouedo, A. and Bordenave, A. (2009) A Quantitative Approach the Role of the Sampling Frequency on the Uncertainties Associated with the Calculation of Flow and Mean Concentrations of Nitrates in Brittany. Engineering, 59, 23-37.

[21] Mama, D., Aina, M., Alassane, A., Boukari, O.T., Chouti, W., Deluchart, V., Bowen, J., Afouda, A. and Baudu, M. (2011) Characterization Physicochemical and Assessing the Risk of Eutrophication of Lake Nokoué (Benin). International Journal of Biological and Chemical Sciences, 5, 2076-2093.

https://doi.org/10.4314/ijbcs.v5i5.29

[22] Guerin, M., Groselin, P., Cordier, S., Viau, C. and Quénel, P. (2003) Panel on Water, National Public Health Institute of Quebec Environment and Health and Practices Public Fondements. Laval University, Quebec.

[23] Brahimi, A. and Shafi, A. (2014) Eco Toxicological Study of Oued Za and Its Tributary Oued Tizeghrane (Lower Moulouya, Eastern Morocco). Journal of Materials 
Environment Sciences, 5, 1671-1682.

[24] El Adouli, J., Chalaoui, A., Berrahou, A., Shafi, A. and Ennabili, A. (2011) Approche de la qualité biologique de l'Oued Ouislame au voisinage des effluents bruts de la région de Meknès. Larhyss Journal, 9, 21-33.

[25] Ohou-Yao, M.J.A., Séka, A.M., Mambo, V., Yapo, O.B., Konan, K.F. and Houénou, P.V. (2014) Contamination des eaux de puits traditionnels par les nitrates sur le bassin versant de la Lobo (Buyo, sud-ouest de la Côte d'Ivoire). Journal of Applied Biosciences, 78, 6654-6665. https://doi.org/10.4314/jab.v78i1.11

[26] Health Canada (2001) Summary of the Recommendations for the Quality of Drinking Water in Canada.

[27] WHO (2004) Guidelines for Drinking Water Quality Recommendation. World Health Organisation, Genève.

[28] Ben Abbou, M., Fadil, F. and El Haji, M. (2014) River Quality Assessment of the City of Taza Used in Irrigation Vegetable Crops (Morocco). Journal of Applied Biosciences, 77, 6462-6473. https://doi.org/10.4314/jab.v77i1.7

[29] Kombiré, O., Adingra, A.A.S., Eblin, G., Aka, N., Kalou, A.C. and Koffi-Nevry, R. (2014) Characterization of Water to an Estuarine Lagoon from the Ivory Coast Aby Lagoon. Larhyss Journal, 20, 95-110.

[30] Kahoul, M. and Touhami, M.I. (2014) Evaluation de la qualité physico-chimique des eaux de consommation de la ville d'Annaba (Algérie). Larhyss Journal, 19, 129-138.

[31] NSI (2015) Estimate from RGPH 1998 the Distribution of Abidjan Common Population by Sex.

[32] Yao, K.M., Yao, K.B., Troukourey, A. and Soro, M.B. (2014) Assessment of Organic Pollution in Tropical Lagoon Bay like Lake (Tiagba Baye Lagoon, Ebrié Lagoon, Ivory Coast). European Journal of Scientific Research, 122, 299-331.

[33] Keddal, H. and Yao N'dri, J. (2007) Impact of Agricultural Intensification on the Quality of Surface Water and Groundwater. HTE Review, 138, 13-29.

[34] Chouti, W., Mama, D., Alassane, A., Changotadé, O., Alapini, F., Boukari, F., Aminou, T. and Afouda, A. (2011) Caractérisation physico-chimique de la lagune de Porto-Novo (sud Bénin) et mise en relief de la pollution par le mercure, le cuivre et le zinc. Journal of Applied Biosciences, 43, 2882-2890. 